\title{
ANALYSIS OF PARTIAL DIALLEL CROSS FOR YIELD AND IT'S COMPONENTS IN DURUM WHEAT
}

(Received: 27. 9. 2010)

\author{
By \\ I. H. Ali and M. A. H. Al-Falahy* \\ Agriculture College, Salahaddin University, Iraq and * Agriculture College, Duhok University, Iraq
}

\begin{abstract}
Eight parents of durum wheat were crossed using partial diallel cross method in the 2008/2009 growing season. The eight parents and their $12 \mathrm{~F}_{1}$ progenies were grown in the 2009/2010 at the Farm of the College of Agriculture, Duhok University, Iraq using a Randomized Complete Block Design with three replications to estimate the general combining ability of the parents, gene action, heritability and heterosis for yield and its components. The results showed highly significant differences among genotypes for all the studied characters. The parent LD $357 \mathrm{E}$ had a positive general combining ability effect in most characters including grain yield. The dominance was greater than additive genetic variance in most the characters. Heritability in narrow sense was high for days to $75 \%$ flowering, 1000-kernel weight and grain yield/plant besides expected genetic advance was high for all characters. Maximum number of hybrids showed significant positive heterosis for 1000-kernel weight and grain yield/plant and the hybrid [Dour 29× LD 357 E] had the highest positive heterosis for most studied characters including grain yield.
\end{abstract}

Key words: combining ability, durum wheat, gene action, heterosis, partial diallel cross.

\section{INTRODUCTION}

Selection of superior parents for hybridization is very important for yield improvement programs (Hasnain et al., 2006). Success in crossing programs depends upon the choice of suitable parental material which will combine well to generate superior progeny. Knowledge of general combining ability (GCA) influencing yield and its components has become increasingly important to plant breeders in the choice of suitable parents for developing potential hybrids in many crop plants (Kruvadi, 1991). For this purpose, several biometrical techniques have been developed which provide information on the genetic worth of parents. Among these techniques, partial diallel method developed by Kempthorn and Curnow (1961) was used to overcome the difficulties at the process of all possible single crosses by diallel cross method especially when the program involves high numbers of inbred lines which cause high sampling error at estimating GCA. This method provides detailed estimations of GCA information regarding the selection of parents possessing high GCA effects, nature of genetic variance and magnitude of each its component, heritability and heterosis.
Based on the combining ability analysis of different characters, higher GCA effects indicate a greater role of the additive gene effects controlling these characters in the plants. The importance of GCA in grain yield and yield components has been evaluated by many researchers. They found that GCA played a more important role in determining yield components. The gene effects and combining ability of yield components were already studied by a number of scientists using diallel analysis (Gorjanovici and KraljevicBalalic, 2005; Joshi et al., 2004; Soylu and Akgun, 2007). Ali and Sadalla (2008) suggested that selection of parents for improvement of wheat grain yield should be based on parental performance and on general combining ability effects.

On the other hand, Habib and Khan (2003), Mahmood et al. (2003) and Riaz and Chowdhry (2003) reported that additive type of gene action with partial dominance was controlling grain yield. But, Inamullah and Hassan (2005) and Hassan et al. (2008), showed that over dominance type of gene action controls this trait. Additive type of gene action with partial dominance was observed for plant height, number of tillers per 
plant, spike length, number of spikelets per spike and grain yield per plant (Sami-ullah et al., 2010), while over-dominance was observed for spike length and non allelic interaction was absent for all the traits studied. However, Kashif et al., (2003) found a dominance gene effect governs spikes/plant and 1000-grain weight. The results obtained by Soylu and Akgun (2007) indicated that narrow sense heritabilities ranged from 0.06 (fertile tiller number) to 0.30 (spike length).

Studies of heterosis also provide useful information about combining ability of the parents and their usefulness in breeding programs (Sharma et al., 1986); so breeders always try to improve yield potential and quality characteristics of wheat. Maximum yield potential can be exploited through hybrid vigor. It has been reported that $72 \%$ percent heterosis was expressed by wheat hybrid for grain yield (Singh et al., 2004). Prasad et al. (1998) reported that grain yield showed maximum heterosis than any other character they studied. Khan and Khan (1996) reported that maximum heterosis was obtained for tillers/plant (31.91\%) followed by grain yield/plant (19.41\%), 1000-kernel weight (17.32\%), and plant height (5.23\%). Chowdhry et al. (2001) observed heterosis for plant height, tillers/plant, 1000-grain weight and grain yield/plant.

The objective of present investigation was to study the general combining abilities, mode of inheritance, heritability and heterosis for yield and its components in $\mathrm{F}_{1}$ hybrids derived by partial diallel crosses of eight durum wheat cultivars under rainfall conditions.

\section{MATERIALS AND METHODS}

This study was carried out in the field of the College of Agriculture, University of Duhok. Iraq. Eight varieties of durum wheat (Triticum durum Desf.) (Senator-capelli [1], Acsad 65 [2], Dour 29 [3], Om-rabi-5 [4], Simeto [5], Crezo [6], Cornella [7] and LD $357 \mathrm{E}$ [8]), were sown during $2008 / 2009$ in a partial diallel crosses program according to Kempthorn and Curnow (1961). The total number of crosses is $n s / 2$, so $n=$ no. of parents $=8$ and $s=$ sample size, which means each variety is to be involved in 3 crosses. The total crosses would be then $8 \times 3 / 2=12$. As per formula the constant $k=(8+1-3) / 2=3$. So the crosses to be attempted are:

$\begin{array}{lll}1 \times 4 & 1 \times 5 & 1 \times 6 \\ 2 \times 5 & 2 \times 6 & 2 \times 7 \\ 3 \times 6 & 3 \times 7 & 3 \times 8 \\ 4 \times 7 & 4 \times 8 & \\ 5 \times 8 & & \end{array}$

Grains of 8 parents and $12 \mathrm{~F}_{1}$ crosses were planted under rainfall conditions in a Randomized Complete Block Design with three replications during 2009-2010. The experimental plot comprised one row of three meters length, with 30 $\mathrm{cm}$ width and $20 \mathrm{~cm}$ plant to plant distance in each replication. At maturity ten guarded plants from each row were tagged randomly and means of the ten plants for each character viz., days to $75 \%$ flowering, plant height $(\mathrm{cm})$, spike length $(\mathrm{cm})$, number of spikes/plant, percentage of spikes/total tillers, 1000-kernel weight (g), biomass yield/plant (g) and grain yield/plant (g) were subjected to analysis of variance according to Al-Rawi and Khalaf-allah (1980) to estimate significant differences among the genotypes. After obtaining the significant differences, data were subjected to the partial diallel analysis according to Kempthorn and Curnow (1961) to estimate general combining ability, variance components (additive and dominance genetic variance and environmental variance), heritability in narrow sense, average degree of dominance, genetic advance and heterosis.

\section{RESULTS AND DISCUSSION}

Analysis of variance for all the characters indicated highly significant differences among genotypes; general and specific combining ability (GCA, SCA). Variances were also significantly different among the $F_{1}$ progenies for all the characters, indicating that there was enough variation to be successful in selecting the desirable cross combinations in this study (Table 1). The mean performance of the parents and the hybrids for different characters are presented in Table (2), earliest days to $50 \%$ flowering observed from parent [2] (128.33 day) among parents and from [2 $\times 7]$ and $[3 \times 6](131.67$ day $)$ among hybrids. The tallest parents were observed in parent [4] (91.67 $\mathrm{cm})$ while maximum plant height (109.33) was recorded in $[3 \times 8]$ hybrid. 
Table (1): Analysis of variance (mean square values) for different characters of the genotypes and hybrids.

\begin{tabular}{|c|c|c|c|c|c|c|c|c|c|}
\hline \multirow[b]{2}{*}{ S O V } & \multirow[b]{2}{*}{ D f } & \multicolumn{8}{|c|}{ Mean squares } \\
\hline & & $\begin{array}{c}\text { Days to } \\
75 \% \\
\text { flowering } \\
\end{array}$ & $\begin{array}{l}\text { Plant } \\
\text { height } \\
\text { (cm) }\end{array}$ & $\begin{array}{l}\text { Spike } \\
\text { length } \\
(\mathbf{c m})\end{array}$ & $\begin{array}{l}\text { No. of } \\
\text { spikes / } \\
\text { plant }\end{array}$ & $\begin{array}{l}\text { Percentage } \\
\text { of spikes / } \\
\text { total tillers }\end{array}$ & $\begin{array}{c}\text { 1000- } \\
\text { kernel } \\
\text { weight }(\mathrm{g})\end{array}$ & $\begin{array}{c}\text { Biomass } \\
\text { yield / } \\
\text { plant(g) }\end{array}$ & $\begin{array}{c}\text { Grain } \\
\text { yield / } \\
\text { plant(g) }\end{array}$ \\
\hline \multicolumn{10}{|c|}{ Genotypes (parents+ hybrids) } \\
\hline Blocks & 2 & 2.52 & 12.02 & 0.20 & 0.42 & 0.004 & 0.09 & 16.26 & 7.28 \\
\hline Genotypes & 19 & $70.82^{* *}$ & $722.86^{* *}$ & $1.84^{* * *}$ & $52.68^{* * *}$ & $0.67^{* *}$ & $3.44^{* *}$ & $894.17^{* *}$ & $194.12^{* * *}$ \\
\hline Error & 38 & 1.18 & 2.81 & 0.23 & 0.66 & 0.002 & 0.03 & 12.27 & 0.42 \\
\hline Total & 59 & & & & & & & & \\
\hline \multicolumn{10}{|c|}{ Hybrids } \\
\hline Blocks & 2 & 1.03 & 4.86 & 0.17 & 0.19 & 0.003 & 0.01 & 27.26 & 5.42 \\
\hline Hybrids & 11 & $79.48^{* *}$ & $784.87^{* *}$ & $1.72^{* *}$ & $56.51^{* *}$ & $0.043^{* *}$ & $3.89^{* *}$ & $837.80^{* *}$ & $237.66^{* *}$ \\
\hline GCA & 7 & $123.73^{* *}$ & $608.23^{* *}$ & $1.01^{* *}$ & $46.38^{* *}$ & $0.047^{* *}$ & $5.26^{* *}$ & $1097.82^{* *}$ & $244.47^{* *}$ \\
\hline SCA & 4 & $3.04^{* *}$ & $1093.98^{* *}$ & $2.97^{* *}$ & $74.24^{* *}$ & $0.036^{* *}$ & $1.50^{* *}$ & $70.823^{* *}$ & $225.75^{* *}$ \\
\hline Error & 22 & 1.57 & 2.29 & 0.23 & 0.74 & 0.002 & 0.003 & 11.74 & 0.58 \\
\hline Total & 35 & & & & & & & & \\
\hline
\end{tabular}

Table (2): Mean performance and statistical significance for the studied characters in parents and hybrids.

\begin{tabular}{|c|c|c|c|c|c|c|c|c|}
\hline Genotype & $\begin{array}{c}\text { Days to } \\
75 \% \\
\text { flowering }\end{array}$ & $\begin{array}{c}\text { Plant } \\
\text { height } \\
(\mathrm{cm})\end{array}$ & $\begin{array}{c}\text { Spike } \\
\text { length } \\
(\mathrm{cm})\end{array}$ & $\begin{array}{l}\text { No. of } \\
\text { spikes / } \\
\text { plant }\end{array}$ & $\begin{array}{l}\text { Percentage } \\
\text { of spikes / } \\
\text { total tillers }\end{array}$ & $\begin{array}{l}\text { 1000-kernel } \\
\text { weight }(\mathrm{g})\end{array}$ & $\begin{array}{c}\text { Biomass } \\
\text { yield / } \\
\text { plant(g) }\end{array}$ & $\begin{array}{c}\text { Grain } \\
\text { yield / } \\
\text { plant(g) }\end{array}$ \\
\hline 1 & $141.00 \mathrm{c}$ & $55.00 \mathbf{j}$ & 8.83 cde & 8.67 ghi & $0.68 \mathbf{g h}$ & $35.40 \mathbf{j k}$ & $62.29 \mathbf{i j}$ & $12.89 \mathbf{i}$ \\
\hline 2 & $128.33 \mathbf{j}$ & $90.67 \mathrm{c}$ & $8.83 \mathrm{cde}$ & $14.33 \mathbf{d}$ & 0.80 cde & $41.37 \mathbf{g h}$ & $86.31 \mathrm{c}$ & $5.56 \mathrm{l}$ \\
\hline 3 & $130.33 \mathbf{i}$ & $66.00 \mathrm{~h}$ & $7.50 \mathbf{f}$ & 10.33 ef & $0.90 \mathbf{b}$ & $42.07 f g$ & 65.91 hi & $14.30 \mathrm{~h}$ \\
\hline 4 & $141.00 \mathrm{c}$ & $91.67 \mathrm{c}$ & $7.50 \mathbf{f}$ & $17.00 \mathbf{c}$ & 0.81 cde & $47.23 \mathbf{e}$ & $101.98 \mathbf{a}$ & $16.83 \mathbf{f}$ \\
\hline 5 & $132.33 \mathbf{g h}$ & $56.00 \mathbf{j}$ & 8.00 ef & $15.67 \mathrm{~cd}$ & $1.00 \mathbf{a}$ & $33.17 \mathbf{k}$ & 73.49defg & $11.03 \mathbf{j}$ \\
\hline 6 & 135.33 ef & $86.33 \mathbf{d}$ & $9.67 \mathbf{a b c}$ & 9.33 fghi & $0.90 \mathbf{b}$ & $54.73 \mathrm{c}$ & 73.26defg & $15.88 \mathrm{fg}$ \\
\hline 7 & $136.33 \mathbf{e}$ & $76.00 \mathbf{f}$ & 8.83 cde & 9.00 fghi & $1.00 \mathbf{a}$ & $51.00 \mathrm{~d}$ & 75.40 def & $15.54 \mathbf{g}$ \\
\hline 8 & $136.00 \mathbf{e}$ & $74.67 \mathbf{f}$ & $9.67 \mathbf{a b c}$ & $6.00 \mathbf{j}$ & $0.50 \mathbf{j}$ & $42.00 \mathbf{f g}$ & $36.67 \mathbf{k}$ & 5.981 \\
\hline $1 \times 4$ & $139.00 \mathrm{~d}$ & $76.67 \mathbf{f}$ & 8.17 def & $8.33 \mathbf{h i}$ & $0.48 \mathbf{j}$ & $62.27 \mathbf{a}$ & $76.61 \mathrm{de}$ & $24.71 \mathrm{c}$ \\
\hline $1 \times 5$ & $145.67 \mathbf{a}$ & $91.00 \mathrm{c}$ & 8.17 def & $8.00 \mathbf{i}$ & $0.63 \mathbf{h i}$ & $37.00 \mathbf{i j}$ & $61.87 \mathbf{i j}$ & 5.181 \\
\hline $1 \times 6$ & $144.00 \mathbf{a b}$ & $61.67 \mathbf{i}$ & $8.67 \mathrm{de}$ & $18.67 \mathbf{b}$ & 0.79 def & $60.87 \mathbf{a b}$ & $107.90 \mathbf{a}$ & $29.25 \mathrm{~b}$ \\
\hline $2 \times 5$ & 135.00 ef & $70.33 \mathbf{g}$ & $9.00 \mathrm{bcd}$ & $15.33 \mathrm{~d}$ & 0.80 cde & 39.00 hi & $77.61 \mathrm{~d}$ & $11.06 \mathbf{j}$ \\
\hline $2 \times 6$ & $133.00 \mathbf{g h}$ & $85.33 \mathrm{~d}$ & 8.17 def & $11.67 \mathrm{e}$ & 0.70 fgh & 44.60 ef & $58.36 \mathbf{j}$ & $10.95 \mathbf{j}$ \\
\hline $2 \times 7$ & $131.67 \mathbf{h i}$ & $85.33 \mathbf{d}$ & 8.17 def & $14.67 \mathrm{~d}$ & 0.87 bcd & $58.17 \mathbf{b}$ & 71.83defgh & $20.60 \mathbf{e}$ \\
\hline $3 \times 6$ & $131.67 \mathbf{h i}$ & $80.00 \mathbf{e}$ & $9.00 \mathrm{bcd}$ & $14.33 \mathbf{d}$ & $0.63 \mathbf{h i}$ & $61.93 \mathbf{a}$ & 70.28efgh & 28.29 b \\
\hline $3 \times 7$ & $132.67 \mathrm{gh}$ & $81.00 \mathbf{e}$ & 8.83cde & 9.67 fgh & $0.88 \mathbf{b c}$ & $58.43 \mathbf{b}$ & $57.20 \mathbf{j}$ & $21.96 \mathbf{d}$ \\
\hline $3 \times 8$ & $134.00 \mathrm{fg}$ & $109.33 \mathbf{a}$ & $9.83 \mathbf{a b}$ & $20.67 \mathbf{a}$ & 0.72 efg & $62.67 \mathbf{a}$ & $98.98 \mathbf{b}$ & $25.10 \mathrm{c}$ \\
\hline $4 \times 7$ & $132.00 \mathbf{h i}$ & $81.67 \mathrm{e}$ & $10.50 \mathbf{a}$ & 10.33 ef & 0.78 ef & $45.4 \mathbf{e}$ & 69.22 fgh & $8.20 \mathbf{k}$ \\
\hline $4 \times 8$ & $136.00 \mathbf{e}$ & $101.67 \mathbf{b}$ & 8.00 ef & $18.67 \mathbf{b}$ & 0.66 ghi & $62.67 \mathbf{a}$ & $98.21 \mathbf{b}$ & $30.37 \mathbf{a}$ \\
\hline $5 \times 8$ & $143.00 \mathbf{b}$ & $49.33 \mathbf{k}$ & $8.67 \mathrm{de}$ & $10.00 \mathbf{f g}$ & $0.59 \mathbf{i}$ & $33.37 \mathbf{k}$ & 67.60 ghi & $13.15 \mathbf{i}$ \\
\hline
\end{tabular}

Means followed by same letter do not differ significantly at 0.05 level of probability by Duncan's Multiple Range Test. 
A comparison of parent means indicated that the parents [6] and [8] had the highest value (9.67 $\mathrm{cm})$ for spike length, while $[4 \times 7]$ hybrid had the highest value $(10.5 \mathrm{~cm})$ among hybrids in this character. The maximum spikes/plant showed in parent [4] (17.00) among parents and (20.67) from [3×8] among hybrids. Greater percentage of spikes/total tillers is directly related with higher grain yield especially under rainfall conditions, so the performance of this character is greatly affected due to reduced availability of soil moisture. The plant strives to complete its life cycle in a short time by reducing its vegetative tillers to enter into reproductive stage (a process called rapid phenological development (Riaz and Chowdhry, 2003); A study of mean values of genotypes revealed that percentage of spikes/total tillers ranged from (0.48) to (1.00) among genotypes, the parental genotype [5] and [7] produced the maximum percentage of spikes/total tillers (1.00) followed by [3] and [6] which produced statistically similar percentage $(0.90)$.
Performance of hybrids indicated that the maximum percentage of spikes/total tillers $(0.88)$ produced by [ $3 \times 7]$ followed by [2×7] $(0.87)$. one thousand-kernel weight is more stable character under rainfall conditions, the results for this character indicated that the parent [6] had the highest value (54.73 g) among parents and (62.67)

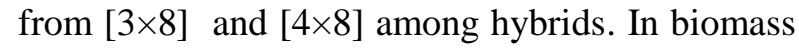
yield/plant, parent [4] gave the highest value $(101.98 \mathrm{~g})$ among parents and [1×6] from hybrids showed the maximum mean value $(107.90 \mathrm{~g})$ for this character. It is further revealed that the parental genotype [4] produced the highest grain yield/plant (16.83 g) while [2] and [8] produced the lowest plant yield 5.56 and $5.98 \mathrm{~g}$, respectively. In the case of hybrids, the maximum grain yield/plant $(30.37 \mathrm{~g})$ was obtained in the hybrid [ $4 \times 8](30.37 \mathrm{~g})$ followed by [1×6] $(29.25$ g) and $[3 \times 6](28.29 \mathrm{~g})$. It was noted that hybrids producing high grain yield/plant involved parent

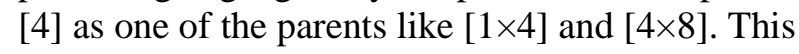
fact indicated the usefulness of this genotype

Table (3): Estimates of GCA effects of parents for the studied characters.

\begin{tabular}{|c|c|c|c|c|c|c|c|c|}
\hline Parent & $\begin{array}{c}\text { Days to } \\
\mathbf{7 5 \%} \\
\text { flowering }\end{array}$ & $\begin{array}{c}\text { Plant } \\
\text { height } \\
(\mathbf{c m})\end{array}$ & $\begin{array}{c}\text { Spike } \\
\text { length } \\
\mathbf{( c m})\end{array}$ & $\begin{array}{c}\text { No. of } \\
\text { spikes / } \\
\text { plant }\end{array}$ & $\begin{array}{c}\text { Percentage } \\
\text { of spikes / } \\
\text { total tillers }\end{array}$ & $\begin{array}{c}\text { 1000-kernel } \\
\text { weight(g) }\end{array}$ & $\begin{array}{c}\text { Biomass } \\
\text { yield / } \\
\text { plant(g) }\end{array}$ & $\begin{array}{c}\text { Grain } \\
\text { yield / } \\
\text { plant(g) }\end{array}$ \\
\hline $\mathbf{1}$ & 6.53 & 6.14 & -0.75 & 0.81 & -0.02 & 0.98 & 14.74 & 5.61 \\
\hline $\mathbf{2}$ & -4.65 & 15.86 & -0.65 & 2.99 & 0.04 & 0.54 & 3.19 & 1.112 \\
\hline $\mathbf{3}$ & -5.18 & 17.60 & 0.38 & 0.35 & -0.03 & 1.02 & -4.77 & 5.06 \\
\hline $\mathbf{4}$ & -4.19 & 5.90 & 0.35 & -2.31 & -0.12 & 0.11 & -4.41 & -0.88 \\
\hline $\mathbf{5}$ & 3.03 & -19.70 & 0.42 & -5.36 & -0.05 & -2.22 & -20.56 & -13.37 \\
\hline $\mathbf{6}$ & 0.85 & -18.64 & 0.19 & 0.15 & -0.01 & -0.49 & -1.84 & -0.16 \\
\hline $\mathbf{7}$ & 0.32 & -11.57 & 0.38 & -2.15 & 0.17 & -0.38 & -8.24 & -3.92 \\
\hline $\mathbf{8}$ & 3.31 & 4.40 & -0.31 & 5.53 & 0.01 & 0.43 & 21.89 & 7.04 \\
\hline SE(gi-gj) & 0.99 & 22.82 & 1.19 & 5.95 & 0.13 & 0.85 & 22.86 & 10.37 \\
\hline
\end{tabular}

Table (4): Estimates of genetic parameters for the studied characters.

\begin{tabular}{|c|c|c|c|c|c|c|c|c|}
\hline Parameter & $\begin{array}{c}\text { Days to } \\
75 \% \\
\text { flowering }\end{array}$ & $\begin{array}{c}\text { Plant } \\
\text { height } \\
\text { (cm) }\end{array}$ & $\begin{array}{c}\text { Spike } \\
\text { length } \\
\text { (cm) }\end{array}$ & $\begin{array}{c}\text { No. of } \\
\text { spikes / } \\
\text { plant }\end{array}$ & $\begin{array}{c}\text { Percentage } \\
\text { of spikes / } \\
\text { total tillers }\end{array}$ & $\begin{array}{c}\text { 1000-kernel } \\
\text { weight }(g)\end{array}$ & $\begin{array}{c}\text { Biomass } \\
\text { yield / } \\
\text { plant(g) }\end{array}$ & $\begin{array}{c}\text { Grain } \\
\text { yield / } \\
\text { plant(g) }\end{array}$ \\
\hline$\sigma^{2} A$ & $\begin{array}{l}31.67 \\
\pm 0.97 \\
\end{array}$ & $\begin{array}{c}157.1 \\
\pm 4.80 \\
\end{array}$ & $\begin{array}{c}0.20 \\
\pm 0.01 \\
\end{array}$ & $\begin{array}{r}11.83 \\
\pm 0.36 \\
\end{array}$ & $\begin{array}{c}0.01 \\
\pm 0.001 \\
\end{array}$ & $\begin{array}{r}1.36 \\
\pm 0.04 \\
\end{array}$ & $\begin{array}{l}175.64 \\
\pm 5.38 \\
\end{array}$ & $\begin{array}{r}63.23 \\
\pm 1.93 \\
\end{array}$ \\
\hline$\sigma^{2} D$ & $\begin{array}{c}0.16 \\
\pm 0.15 \\
\end{array}$ & $\begin{array}{r}363.90 \\
\pm 70.03 \\
\end{array}$ & $\begin{array}{c}0.91 \\
\pm 0.18 \\
\end{array}$ & $\begin{array}{r}24.50 \\
\pm 4.72 \\
\end{array}$ & $\begin{array}{c}0.02 \\
\pm 0.002 \\
\end{array}$ & $\begin{array}{c}0.50 \\
\pm 0.10 \\
\end{array}$ & $\begin{array}{r}362.03 \\
\pm 69.68 \\
\end{array}$ & $\begin{array}{r}75.06 \\
\pm 14.44 \\
\end{array}$ \\
\hline$\sigma^{2} \mathrm{E}$ & $\begin{array}{r}1.57 \\
\pm 0.45 \\
\end{array}$ & $\begin{array}{r}2.29 \\
\pm 0.66 \\
\end{array}$ & $\begin{array}{r}0.23 \\
\pm 0.07 \\
\end{array}$ & $\begin{array}{r}0.74 \\
\pm 0.21 \\
\end{array}$ & $\begin{array}{r}0.002 \\
\pm 0.001 \\
\end{array}$ & $\begin{array}{c}0.003 \\
\pm 0.001 \\
\end{array}$ & $\begin{array}{r}11.74 \\
\pm 3.39 \\
\end{array}$ & $\begin{array}{c}0.58 \\
\pm 0.17 \\
\end{array}$ \\
\hline$\overline{\mathbf{a}}$ & 0.1 & 2.15 & 3.01 & 2.03 & 1.40 & 0.86 & 2.03 & 1.54 \\
\hline h.n.s. & 0.95 & 0.30 & 0.15 & 0.32 & 0.46 & 0.73 & 0.32 & 0.46 \\
\hline GA & 9.64 & 12.09 & 0.31 & 3.42 & 0.13 & 1.76 & 13.19 & 9.44 \\
\hline $\begin{array}{l}\text { GA }(\% \text { of } \\
\text { mean })\end{array}$ & 7.08 & 14.71 & 3.51 & 25.36 & 18.00 & 33.26 & 17.23 & 49.12 \\
\hline Mean & 136.31 & 82.14 & 8.76 & 13.49 & 0.72 & 52.77 & 76.52 & 19.22 \\
\hline
\end{tabular}

$\sigma^{2} A=$ Additive genetic variance; $\sigma^{2} \mathrm{D}=$ Dominance genetic variance; $\sigma^{2} \mathrm{E}=$ Environment variance; $\overline{\mathbf{a}}=\mathrm{Average}$ degree of dominance $\mathbf{h}_{\text {.n.s. }}$ heritability in narrow sense; $\mathrm{GA}=$ Genetic advance. 
under rainfall conditions. Similarly, significant differences among genotypes for grain yield and related characters in different sets of material of wheat were also reported (Budak, 2001, Kashif et al., 2003, Riaz and Chowdhry, 2003, Singh et al., 2004, Bhutta et al., 2005, Hasnain et al., 2006, Akbar et al., 2007, Dagustu, 2008 and Ullah et al., 2010).

Effects of general combining abilities estimated for the parents were presented in (Table 3). For days to $75 \%$ flowering, plant height, spike length, number of spikes/plant, percentage of spikes/total tillers, 1000-kernel weight, biomass yield/plant, and grain yield/plant, parental genotypes [1], [3], [5], [8], [7], [3], [8] and [8] were the best combiners while [3], [5], [1], [5], [5], [5], [5] and [5] were the poorest combiners, respectively. In other words, the parents having higher GCA values contributed more to the characters considered than the others. For example, the parent [8] that has the highest GCA effect for the number of spikes/plant, biomass yield/plant and grain yield/plant had more contribution to these characters than the others in their hybrids. Similar results have been reported by other researchers (Budak 2001, Joshi et al., 2004 and Dagustu 2008).

Table (4) presents estimates of additive genetic variance, dominance genetic variance, environmental variance, average degree of dominance, heritability in the narrow sense and genetic advance for the studied characters. The dominance genetic variance was more than the additive genetic variance for all characters except days to $75 \%$ flowering and 1000-kernel weight. This indicates the preponderance of over dominance gene effect in the genetic control of these characters. This result is supported by the values of the average degree of dominance which is greater than one for these characters. The role of the over dominance gene effect was also reported for grain yield and its components in wheat by Sharma and Singh (1983) and Khan and Habib, 2003). High heritability to medium in the narrow sense was reported for days to $75 \%$ flowering, percentage of spikes/total tillers, 1000kernel weight and grain yield/plant and medium to low for plant height, number of spikes/plant and biomass yield/plant, whereas low heritability in the narrow sense was observed for spike length only. The genetic advance in absolute and relative was high for all characters except for spike length. High heritability values and high percentage of genetic advance indicate scope for improvement of these characters by direct selection. The present finding supported the results of Dixit et al. (1970), who also reported that to make an effective selection, high heritability should be associated with high genetic advance.

The range of heterosis and the number of hybrids showing significant desirable heterosis over mid-parent for all the eight characters are presented in Table (5). Results of hybrids showing heterosis revealed that maximum number of hybrids showed heterosis for 1000-kernel weight, grain yield/plant, plant height, number of spikes/plant, biomass yield/plant, spike length and days to $75 \%$ flowering. The heterosis values estimated for all characters of hybrids are given in Table (6). Hybrid [ $1 \times 5]$ had the highest positive heterosis for days to $75 \%$ flowering and [ $4 \times 7]$ had the lowest days to $75 \%$ flowering. Low heterosis for this character especially under rainfall conditions is desirable because the high temperatures and moisture deficit occurred during the grain filling period. Six out of twelve hybrids showed positive heterosis in plant height, the $[3 \times$ $8]$ hybrid gave the highest value of heterosis (39.00) while $[1 \times 6]$ hybrid gave the lowest value of heterosis (-9.00). The negative estimates of heterosis for plant height are preferred in wheat breeding because dwarfness is a desirable character (Budak and Yilidrim, 1996). Positive heterosis was observed in two hybrids in spike length, the hybrids $[4 \times 7]$ showed the highest value for heterosis (2.33). For number of spikes/plant, $[3 \times 8](12.50),[1 \times 6](9.67),[4 \times 8]$ $(7.17),[3 \times 6](4.50)$ and $[2 \times 7](3.00)$ hybrids had the highest values of heterosis. But in percentage of spikes/total tillers, hybrids exhibited non-significant heterosis. Heterosis values of the hybrids for 1000-kernel weight varied from -4.2120.95. Ten out of twelve hybrids showed positive heterosis. [1 $\times 4](20.95),[3 \times 8](20.53)$ and $[4 \times$ 8] (18.05) showed high values for heterosis followed by $[1 \times 6](15.80)$. Hybrids [ $3 \times 8],[1 \times$ 6], [4 $\times 8]$ and $[5 \times 8]$ exhibited highly significant heterosis for biomass yield/plant $(47.00,40.12$, 28.89 and 12.52, respectively). It could be concluded that three of these hybrids involving one common parent [8] exhibited significant heterosis for this character. For grain yield/plant the results indicated that $75 \%$ of hybrids showed positive heterosis; these hybrids are $[1 \times 4],[3 \times 8]$, $[1 \times 6],[4 \times 8],[3 \times 6],[3 \times 7],[2 \times 7],[1 \times 5]$ and $[2 \times 5]$ which showed highest heterosis of grain yields/plant among the hybrids; 2.10, 2.05, 1.81, $1.85,1.20,1.19,0.27$ and 0.17 , respectively. 
Table (5): Range of heterosis and number of desirable hybrids for studied characters.

\begin{tabular}{|l|l|l|l|}
\hline Days to 75\% flowering & $\mathbf{1}[9.00-(-6.66)]$ & Percentage of spikes / total tillers & $\mathbf{0}[-0.26-0.02]$ \\
\hline Plant height $(\mathbf{c m})$ & $\mathbf{6}[-16.00-39.00]$ & $1000-$ kernel weight $(\mathrm{g})$ & $\mathbf{1 0}[-4.21-20.95]$ \\
\hline Spike length $(\mathbf{c m})$ & $\mathbf{2}[-1.08-2.33]$ & $\begin{array}{l}\text { Biomass yield / } \\
\text { plant }(\mathrm{g})\end{array}$ & $\mathbf{4}[-21.42-47.69]$ \\
\hline No. of spikes / plant & $\mathbf{5}[-4.50-12.50]$ & Grain yield / plant $(\mathrm{g})$ & $\mathbf{9}[-0.42-2.10]$ \\
\hline
\end{tabular}

Table (6): Heterosis relative to the mid-parent for studied characters.

\begin{tabular}{|c|c|c|c|c|c|c|c|c|}
\hline Genotype & $\begin{array}{c}\text { Days to } \\
75 \% \\
\text { flowering }\end{array}$ & $\begin{array}{c}\text { Plant } \\
\text { height } \\
(\mathrm{cm})\end{array}$ & $\begin{array}{c}\text { Spike } \\
\text { length } \\
(\mathrm{cm})\end{array}$ & $\begin{array}{c}\text { No. of } \\
\text { spikes / } \\
\text { plant } \\
\end{array}$ & $\begin{array}{c}\text { Percentage } \\
\text { of spikes / } \\
\text { total tillers }\end{array}$ & $\begin{array}{c}\text { 1000-kernel } \\
\text { weight }(\mathrm{g})\end{array}$ & $\begin{array}{c}\text { Biomass } \\
\text { yield / } \\
\text { plant }(g)\end{array}$ & $\begin{array}{c}\text { Grain } \\
\text { yield / } \\
\text { plant(g) }\end{array}$ \\
\hline $1 \times 4$ & -2.00 & $3.33^{*}$ & 0.00 & $-4.50^{* * *}$ & $-0.26^{* *}$ & $20.95^{* *}$ & -5.52 & $2.10^{* * *}$ \\
\hline $1 \times 5$ & $9.00^{* *}$ & $35.50^{* *}$ & -0.25 & $-4.17^{* *}$ & $-0.21^{* * *}$ & $2.72^{* *}$ & -6.03 & $0.27^{* *}$ \\
\hline $1 \times 6$ & $5.83^{* *}$ & $-9.00^{* * *}$ & -0.58 & $9.67^{* *}$ & 0.00 & $15.80^{* *}$ & $40.12^{* *}$ & $1.58^{* * *}$ \\
\hline $2 \times 5$ & $4.67^{* *}$ & -3.00 & 0.58 & 0.33 & $-0.10^{*}$ & $1.73^{* *}$ & -2.29 & $0.17^{*}$ \\
\hline $2 \times 6$ & 1.17 & -3.17 & -1.08 & -0.17 & $-0.15^{* * *}$ & $-3.45^{* * *}$ & $-21.42^{* * *}$ & $-0.35^{* * *}$ \\
\hline $2 \times 7$ & -0.67 & 2.00 & -0.67 & $3.00^{* * *}$ & -0.03 & $11.98^{* *}$ & $-9.02^{*}$ & $1.19^{* *}$ \\
\hline $3 \times 6$ & -1.17 & $3.83^{*}$ & 0.42 & $4.50^{* * *}$ & $-0.28^{* * *}$ & $13.50^{* * *}$ & 0.70 & $1.35^{* *}$ \\
\hline $3 \times 7$ & -0.67 & $10.00^{* *}$ & 0.67 & 0.00 & -0.08 & $11.90^{* * *}$ & $-13.45^{* *}$ & $1.20^{* *}$ \\
\hline $3 \times 8$ & 0.83 & $39.00^{* *}$ & $1.25^{*}$ & $12.50^{* *}$ & 0.02 & $20.53^{* *}$ & $47.69^{* *}$ & $2.05^{* *}$ \\
\hline $4 \times 7$ & $-6.66^{* *}$ & -2.17 & $2.33^{* * *}$ & $-2.67^{* * *}$ & $-0.12^{* *}$ & $3.71^{* * *}$ & $-19.47^{* *}$ & $-0.37^{* *}$ \\
\hline $4 \times 8$ & $0-2.5$ & $18.50^{* *}$ & -0.58 & $7.17^{* *}$ & 0.01 & $18.05^{* *}$ & $28.89^{* *}$ & $1.81^{* *}$ \\
\hline $5 \times 8$ & $8.83^{* *}$ & $-16.00^{* * *}$ & -0.17 & -0.83 & $-0.16^{* *}$ & $-4.21^{* *}$ & $12.52^{* * *}$ & $-0.42^{* *}$ \\
\hline
\end{tabular}

These results are agree to some earlier findings (Budak 2001, Chowdhry et al., 2001, Singh et al.,2004, Farooq et al., 2005 and Akbar et al., 2007). However, high heterosis for grain yield has been reported by several wheat workers in the past and some reported grain yield to show maximum heterosis than any other character they studied (Singh et al., 2004). The results of the present study exhibited that the hybrids showing heterosis for grain/plant were not heterotic for other characters. These causes confusion for the plant breeder especially when he desires to select the superior genotype for many characters. We found

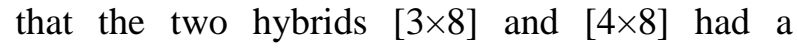
remarkable significant positive heterosis for most characters (6 and 5 characters, respectively) including grain yield, which indicate efficient selection in segregation generations, especially, they include the parent [8] which showed positive general combining ability effect in most characters.

\section{REFERENCES}

Akbar M., Arif Khan M., Aziz-ur-Rehman and Ahmad N. (2007). Heterosis and heterobeltiosis for improvement of wheat grain yield. J. Agric. Res., 45(2): 87- 94.

Ali I. H. and Sadalla H. A. (2008). Analysis of combining ability and gene action for diallel crosses of two generations in durum wheat. Zanco J., 20 (4): 31- 40.

Al-Rawi K. M. and Khalaf-allah M. A. (1980). Design and Analysis of Agricultural 
Experiments. Mosul University Press., (In Arabic).

Bhutta W. M., Akhtar J., Anwar-ul-Haq M. and Ibrahim M. (2005). Estimation of heritability of some important traits in spring wheat (Triticum aestivum L.). Caderno de Pesquisa Ser. Bio., Santa Cruz do Sul, 17(1): 20- 27.

Budak N. (2001). Heterosis and combining ability in $8 \times 8$ diallel durum wheat population. Ege. Uni. Ziraat. Fak. Derg., 38:55- 62.

Budak N. and Yilidrim M. B. (1996). Heterosis in bread wheat. Tur. J. Agric. Forest. 20: 345347.

Chowdhry M. A., Iqbal M., Subhani G. M. and Khaliq I. (2001). Heterosis, inbreeding depression and line performance in crosses of Triticum aestivum. Pak. J. Biol. Sci., 4 (1): $56-58$.

Dagustu N. (2008). Genetic analysis of grain yield per spike and some agronomic traits in Diallel crosses of bread wheat (Triticum aestivum L.). Turk. J. Agric For., 32: 249258.

Dixit P. K., Sexena P. D. and Bhatia L. K. (1970). Estimation of genotypic variability of some quantitative characters in groundnut. Indian J. Agric. Sci., 40: 197-201.

Farooq J., Habib I.and Khaliq I. (2005). Diallel analysis to predict utilization of heterosis and heterobeltiosis in yield and yield components of bread wheat. J. Agric. Res., 43 (3):171-182.

Gorjanovici B. and Kraljevic- Balalic M. (2005). Inheritance of plant height and spike length in wheat. Genetika, 37 (1): 2531.

Habib I. and Khan A. S. (2003). Genetic model of some economic traits in bread wheat (Titicum aestivum L.). Asian J. Plant Sci., 2: 1153- 1154.

Hasnain Z., Abbas G., Saeed A. and Shakeel A. (2006). Combining ability for plant height and yield related traits in wheat, Triticum aestivum. J. Agric. Res., 44(3): 167- 173.

Hassan S. E., Khaliq I. and Khan A. S. (2008). Genetic mechanism of some physiological traits in spring wheat at two plant population regimes. J. Agric. Res., 46: 395401.

Inamullah F. M. and Hassan G. (2005). Genetics of important traits in bread wheat using diallel analysis. Sarhad J. Agric., 21: 617622.
Joshi S. K., Sharma S. N., Singhania D. L. and Sain R. N. (2004). Combining ability in the $\mathrm{F} 1$ and $\mathrm{F} 2$ generations of diallel cross in hexaploid wheat (Triticum aestivum $\mathrm{L}$. em. Thell). Hereditas, 141:115-121.

Kashif M., Ahmad J. Chowdhry M. A. and Perveen K. (2003). Study of genetic architecture of some important agronomic traits in durum wheat (Triticum durum Desf.). Asian J. Pl. Sci., 2:708-712.

Kempthorn O. and Curnow R. N. (1961). The partial diallel cross. Biometrics, 17:229251.

Khan A. and Habib I. (2003). Gene action in a five parent diallel cross of spring wheat (Triticum aestivum L.). Pakistan J. Biol. Sci., 6:1945-1948.

Khan M. A. and Khan A. S. (1996). Heterosis studies for yield and yield components in some crosses of bread wheat. Pak. J. Agri. Sci., 33(1): 66-68.

Kruvadi S. (1991). Diallel analysis and heterosis for yield and associated characters in durum wheat under upland conditions. Turrialba Publ., 41 (3): 335- 338.

Mahmood N., Chowdhry M. A. and Kashif M. (2003). Genetic analysis of some physiomorphic traits of wheat (Triticum aestivum L.) under drought condition. Pakistan. J. Genet. Breed., 57: 385- 391.

Prasad K D., Haque M. F. and Ganguli D. K. (1998). Heterosis studies for yield and its components in bread wheat. Indian $\mathrm{J}$. Genet., 58: 97- 100.

Riaz R. and Chowdhry M. A. (2003). Genetic analysis of some economic traits of wheat under drought conditions. Asian J. Plant Sci., 2: 790- 796.

Sami-ullah K., A., Raza A. and Sadique S. (2010). Gene action analysis of yield and yield related traits in spring wheat (Triticum aestivum). Int. J. Agric. Biol., 12(1): 125128.

Sharma S. K. and Singh R. K. (1983). Combining ability for harvest index and its components in wheat. Indian J. Genet., 43: 229-231.

Sharma S. K., Singh I. and Singh K. P. (1986). Heterosis and combining ability in wheat. Crop improvement, 13: 101- 103.

Singh H., Sharma S. N. and Sain R. S. (2004). Heterosis studies for yield and its components in bread wheat over environments.Hereditas.141:106-114.

Soylu S. and Akgun N. (2007). Combining ability and inheritance of some agronomical traits 
in bread wheat (Triticum aestivum L.). Ziraat Fakultesi Dergisi., 21(41): 104- 108.

Ullah S., Khan A. S., Raza A and Sadique S. (2010). Gene action analysis of yield and yield related traits in spring wheat (Triticum aestivum). Int. J. Agric. Biol., 12: 125-128.

\author{
تحليل التهجين التبادلي الجزئي للحاصل ومكوناته في الحنطة الخشنة \\ اسماعيل حسين علي- عحم علي حسين الفلاحي* \\ كلية الزر اعة ـ جامعة صلاح الدين ـ العراق ـ * كلية الزر اعة ـ جامعة دهوك ـ العراق
}

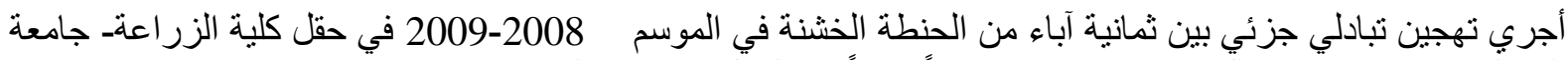

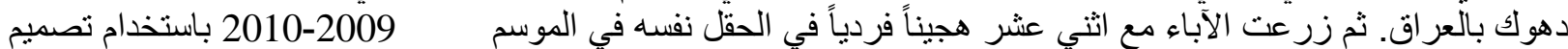

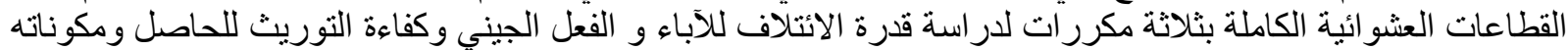

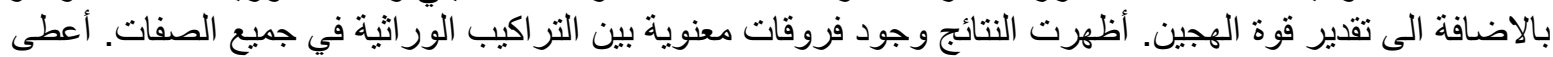
الأب ED 357 E تأثير ات قدرة ائتلاف عامة موجبة في أكثر عدد من الصفات بضمنها حاصل الحبوب، وكانت قيم التباين

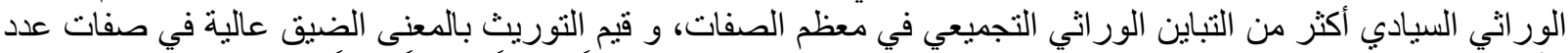

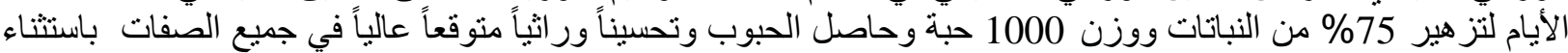

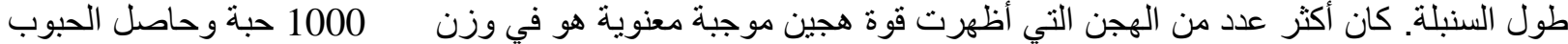
و أظهر الهجين [Dour 29 × LD 357 E] قوة هجين موجبة في أكثر عدد من الصفات بضمنها حاصل الحبوب.

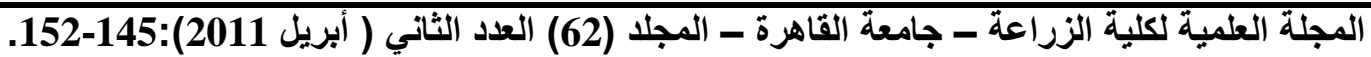

